W. Van de Vrie $\cdot$ J. H. M. Schellens

W. J. Loos - H. J. Kolker · J. Verwey

G. Stoter - N. M. C. Durante - A. M. M. Eggermont

\title{
Modulation of multidrug resistance with dexniguldipine hydrochloride (B8509-035) in the CC531 rat colon carcinoma model
}

Received: 8 September 1995/Accepted: 10 January 1996

\begin{abstract}
The chemosensitizing potency of dexniguldipine hydrochloride (B8509-035) on epidoxorubicin was assessed in a multidrug-resistant (MDR) tumour model, the intrinsic MDR rat colon carcinoma CC531. In vitro in the sulphorhodamine $B$ cell-viability assay the cytotoxicity of epidoxorubicin was increased approximately 15 -fold by co-incubation with $50 \mathrm{ng} / \mathrm{ml}$ dexniguldipine. In vivo concentrations of dexniguldipine $5 \mathrm{~h}$ after a single oral dose of $30 \mathrm{mg} / \mathrm{kg}$ were 72 $( \pm 19 \mathrm{SD}) \mathrm{ng} / \mathrm{ml}$ in plasma and $925( \pm 495 \mathrm{SD}) \mathrm{ng} / \mathrm{g}$ in tumour tissue. Levels of the metabolite of dexniguldipine, M-1, which has the same chemosensitizing potential, were $26( \pm 6 \mathrm{SD}) \mathrm{ng} / \mathrm{ml}$ and 289 ( $\pm 127 \mathrm{SD}$ ) $\mathrm{ng} / \mathrm{g}$ respectively. The efficacy of treatment with $6 \mathrm{mg} / \mathrm{kg}$ epidoxorubicin applied intravenously combined with $30 \mathrm{mg} \mathrm{kg}^{-1} \mathrm{day}^{-1}$ dexniguldipine administered orally for 3 days prior to epidoxorubicin injection was evaluated on tumours grown under the renal capsule. Dexniguldipine alone did not show antitumour effects in vivo. Dexniguldipine modestly, but consistently, potentiated the tumour-growth-inhibiting effect of epidoxorubicin, reaching statistical significance in two out of four experiments. In conclusion, these experiments show that dexniguldipine has potency as an MDR reverter in vitro and in vivo in this solid MDR tumour model.
\end{abstract}

\footnotetext{
W. Van de Vrie - A. M. M. Eggermont ( $\square$ )

Department of Surgical Oncology, Rotterdam Cancer Institute, Groene Hilledijk 301, 3075 EA Rotterdam, The Netherlands. Fax: 31104864645

W. Van de Vrie - N. M. C. Durante - A. M. M. Eggermont Laboratory for Experimental Surgery, Erasmus University, PO Box 1738, 3000 DR Rotterdam, The Netherlands

J. H. M. Schellens - W. J. Loos - H. J. Kolker · J. Verwey G. Stoter

Department of Medical Oncology, Rotterdam Cancer Institute, Groene Hilledijk 301, 3075 EA Rotterdam, The Netherlands
}

Key words Chemosensitizer - Dexniguldipine . Epidoxorubicin - Multidrug resistance $\cdot$ in vivo

\begin{abstract}
Abbreviations $M D R$ multidrug resistance $\cdot P B S$ phosphate-buffered saline
\end{abstract}

\section{Introduction}

Multidrug resistance (MDR) is an important mechanism in clinical drug resistance and expression of the $m d r$ gene is found in a variety of tumours (Bellamy and Dalton 1994; Goldstein et al. 1989). In MDR a transmembrane efflux pump, P-glycoprotein, confers drug resistance on a group of chemically unrelated anticancer drugs by increasing the efflux. The P-glycoprotein pump can be blocked reversibly by so-called chemosensitizers, which are substrates for the protein themselves. As a result, higher intracellular levels of anticancer drugs are achieved and enhanced cell death occurs. Among the various compounds that can function as chemosensitizers are verapamil, cyclosporin A and its non-immunosuppressive analogue PSC 833, quinidine, tamoxifen, and many others (Bellamy and Dalton 1994). Previous studies have been carried out with verapamil, but levels necessary for modulation of MDR in vivo appeared too high, resulting in severe cardiovascular side-effects. In a clinical trial with verapamil, dose-limiting side-effects were hypotension and cardiac arrhythmias at levels of exposure anticipated to be inadequate for MDR reversal (Pennock et al. 1991). This has led to a search for related compounds that are devoid of the cardiovascular side-effects.

Stereoisomers of verapamil and related drugs vary in calcium-channel-blocking activity. For example, the $(+)$ stereoisomer of verapamil is a 10 -fold less potent calcium antagonist than the (-)isomer (Echizen et al. 1985), but has approximately the same chemosensitizing effectiveness (Plumb et al. 1990). Of the other calcium antagonists, the dihydropyridine drug 
niguldipine, was found to be a very effective chemosensitizer in MDR (Höllt et al. 1992). The (-)stereoisomer, dexniguldipine hydrochloride (B8509-035), displays a 45-fold lower affinity for calcium-channel-binding sites compared to the $(+)$ isomer, while both have the same MDR-modulating potency (Höllt et al. 1992). In various preclinical models in vitro the chemosensitizing potency of dexniguldipine was either equal to or up to 50 times more effective than verapamil (Hill and Hosking 1994; Hofmann et al. 1991, 1992; Höllt et al. 1992; Reymann et al. 1993; Roller et al. 1993).

We tested the activity of dexniguldipine in the CC531 MDR tumour model. CC531 is a colon carcinoma, derived from and transplantable in the WAG/RIJ rat, that intrinsically expresses the multidrug-resistant phenotype. In a previous report the potency of cyclosporin $\mathrm{A}$ as a modulator of resistance to doxorubicin was shown in this model (Van de Vrie et al. 1993). Here we report on the chemosensitizing effect of dexniguldipine in vitro and in vivo and on levels of dexniguldipine and its active metabolite $\mathrm{M}-1$ in plasma and tumours.

\section{Materials and methods}

\section{Animals}

Male rats of the inbred WAG/RIJ (RT1 ${ }^{u}$ ) strain were obtained from Harlan-CPB (Austerlitz, The Netherlands). Animals were bred under specific-pathogen-free conditions and fed standard rat chow (Hope Farms, Woerden, The Netherlands) and water ad libitum. In the experiments rats $12-18$ weeks old, weighing $220-280 \mathrm{~g}$, were used.

\section{Tumour and cell line}

CC531 is a colon carcinoma, which was induced chemically in the WAG/RIJ rat with 1,2-dimethylhydrazine. The tumour, a moderately differentiated adenocarcinoma, is weakly immunogenic and transplantable in WAG/RIJ rats (Marquet et al. 1984). In vitro the cell line grows as a monolayer. CC.531 is an intrinsically multidrugresistant tumour as it expresses the MDR phenotype. At the mRNA level, expression of $m d r-1 a$, and not $m d r-1 b$, has been detected by the polymerase chain reaction (De Greef et a1. 1995). A low level of P-glycoprotein expression has been shown with the monoclonal antibody C-219 by Western blotting and by immunofluorescence techniques (De Greef et al. 1995; Van de Vrie et al. 1993). Intracellular accumulation of daunorubicin can be enhanced by chemosensitizers like verapamil and cyclosporin A (Gheuens et al. 1993; Van de Vrie et al. 1993). Cytotoxicity assays have shown the typical drug-resistance pattern of MDR and enhancement of cytotoxicity by chemosensitizers (Gheuens et al. 1993; Van de Vrie et al. 1993).

The cell line was grown in Dulbecco's modified Eagle's medium supplemented with $5 \%$ fetal calf serum, aspartic acid $(0.1 \mathrm{mM})$, glutamic acid $(0.3 \mathrm{mM})$, penicillin $(111 \mathrm{IU} / \mathrm{ml})$ and streptomycin $(111 \mu \mathrm{g} / \mathrm{ml})$, all obtained from Gibco (Paisley, UK), in a humidified atmosphere of $5 \% \mathrm{CO}_{2} / 95 \%$ air at $37^{\circ} \mathrm{C}$. Regular screening for Mycoplasma infection was performed. Cells were isolated by trypsinization; viability, determined by trypan blue exclusion, was over $90 \%$ in all experiments.

\section{Chemicals}

Dexniguldipine hydrochloride (B8509-035), the metabolite M-1 (B8909-008) and B89003-001 (internal standard for dexniguldipine in the HPLC) were kindly provided by Byk Gulden, Konstanz, Germany; epidoxorubicin (Farmorubicin) was obtained from Farmitalia, Carlo Erba, Italy; sulphorhodamine B (SRB) was purchased from Sigma Chemicals, St. Louis, M., USA; deionized Milli-Q water was from Millipore, Etten Leur, The Netherlands; trichloroacetic acid from J.T. Baker, Deventer, The Netherlands; and dichloromethane/hexane/isobutyl alcohol (40:60:0.5) from Rathburn, Walkerburn, Scotland.

In vitro cytotoxicity assay

Chemosensitivity in vitro was determined with the sulphorhodamine B cell-viability assay, essentially carried out as described by Skehan et al. (1990). In brief, $2 \times 10^{3}$ trypsinized tumour cells/well in $200 \mu \mathrm{l}$ complete medium were plated into 96-well flat-bottomed microtitre plates (Costar, Cambridge, Mass., USA). Tests were carried out in quadruplicate. The plates were incubated for $24 \mathrm{~h}$ at $37^{\circ} \mathrm{C}, 5 \% \mathrm{CO}_{2} / 95 \%$ air to allow the cells to adhere. Then the old medium was replaced by medium containing the test drug in graded concentrations; in the interaction studies epidoxorubicin together with a fixed concentration of dexniguldipine was added. On day 7 the incubation was terminated by washing the plates twice with phosphate-buffered saline (PBS). Subsequently the cells were fixed with $10 \%$ trichloroacetic acid in deionized Milli-Q water and placed for $1 \mathrm{~h}$ at $4^{\circ} \mathrm{C}$. After five washings with tap water, the cells were stained for 15 min with $0.4 \%$ sulphorhodamine $B$ dissolved in $1 \%$ acetic acid, and subsequently washed with $1 \%$ acetic acid to remove the unbound stain. The plates were air-dried and bound protein stain was dissolved in $150 \mu \mathrm{l} 10 \mathrm{mM}$ TRIS base. The absorbance was read at $540 \mathrm{~nm}$ using an automated microplate reader (Titertek, Flow Laboratories Ltd., Irvine, Scotland).

In vivo assay

Subcutaneously grown solid tumours of the CC531 cell line were used 20-30 days after implantation. In a subrenal capsule assay tumour pieces weighing 6-8 $\mathrm{mg}$ were implanted under the capsule of the kidneys. In the pharmacokinetic experiment, treatment with dexniguldipine was given 10 days after implantation. Rats were restrained from food $12 \mathrm{~h}$ prior to administration of the drug. A single dose of $30 \mathrm{mg} / \mathrm{kg}$ dexniguldipine was administered orally through a thin metal cannula. Five hours later rats were sacrificed, a blood sample was taken and the tumours were collected for analysis of dexniguldipine and M-1 levels.

In the pharmacodynamic experiment dexniguldipine treatment was started $24 \mathrm{~h}$ after implantation of the tumour. In contrast to the single dosing in the pharmacokinetic experiment, dexniguldipine was administrated for 3 consecutive days orally at a dose of $30 \mathrm{mg} \mathrm{kg}^{-1} \mathrm{day}^{-1}$. On day $4,5 \mathrm{~h}$ after the last dexniguldipine dose, rats were injected intravenously with $6 \mathrm{mg} / \mathrm{kg}$ epidoxorubicin, or PBS in control rats. On day 10 animals were sacrificed, tumours were enucleated and weighed.

All experimental groups consisted of $6-8$ rats.

Apparatus for dexniguldipine and M-1 measurement

Dexniguldipine was determined in plasma and tumour tissue with an automated reverse-phase isocratic high-performance liquid chromatography (HPLC) assay with UV detection at $230 \mathrm{~nm}$. A model 710B WISP autosampler and a model M510 pump were 
used (all Waters Assoc., Milford, Mass., USA). The detector was a UV2000 (Spectra Physics, San Jose, Calif, USA). The data were processed with a Shimadzu CR3A integrator (Shimadzu Corp., Kyoto, Japan). The column was a Shandon Hypersyl CPS, $3 \mu \mathrm{m}$ $150 \times 4.6 \mathrm{~mm}$ (LC Services, Emmen, The Netherlands). The eluent consisted of a $5 \mathrm{mM}$ phosphate buffer $(\mathrm{pH} 7.5$ ) with $60 \%$ acetonitrile. The flow rate was $1.5 \mathrm{ml} / \mathrm{min}$ and the column temperature $40^{\circ} \mathrm{C}$. Sample size was $100 \mu \mathrm{l}$ for each analysis.

Sample preparation for dexniguldipine and M-1 measurement.

A volume of $150 \mu \mathrm{l}$ plasma was collected, to which $50 \mu 12000 \mathrm{ng} / \mathrm{ml}$ solution of internal standard (B89003-001) in methanol was added. Next, $800 \mu$ deionized Milli-Q water was added and the sample was mixed on a whirl mixer for $15 \mathrm{~s}$. For extraction of the test chemicals $7 \mathrm{ml}$ dichloromethane/hexane/isobutyl alcohol $(40: 60: 0.5)$ was added. The mixture was mixed for $30 \mathrm{~min}$ on a whirl mixer and subsequently centrifuged for $10 \mathrm{~min}$ at $4000 \mathrm{~g}$. The organic layer was collected and evaporated to dryness at $50^{\circ} \mathrm{C}$ under vacuum. The residue was reconstituted in $150 \mu$ l eluent.

Tumour tissue was homogenized with a Turrax homogenizer (Boom, Meppel, The Netherlands) in $1 \mathrm{ml}$ Milli-Q water. The homogenizer was flushed twice with $250 \mu \mathrm{l}$ Milli-Q water. A $50-\mu 1$ volume of a $2000-\mathrm{ng} / \mathrm{ml}$ internal standard solution in methanol and $7 \mathrm{ml}$ dichloromethane/hexane/isobutyl alcohol (40:60:0.5) were added. Further handling of the tissue sample was as described for the plasma sample.

The recovery of dexniguldipine, $\mathrm{M}-1$, and the internal standard was determined relative to direct injection of the individual dissolved compounds.

\section{Statistics}

Statistical analysis was carried out with SPSS $/ \mathrm{PC}+$, using the Mann-Whitney $U /$ Wilcoxon rank-sum $W$-test. $P<0.05$ was considered significant.

\section{Ethical approval}

The experimental protocols adhered to the rules laid down in The Dutch Animal Experimentation Act (1977) and the Guidelines on the Protection of Experimental Animals published by the Council of the E.C. (1986). Specific protocols were approved by the Committee on Animal Research of the Erasmus University, Rotterdam.

\section{Results}

In vitro chemosensitizing effect of dexniguldipine on epidoxorubicin

Dexniguldipine up to $1000 \mathrm{ng} / \mathrm{ml}$ had less than $10 \%$ growth-inhibiting effect on CC531 cells in vitro. The median inhibitory dose (ID 50 ) for dexniguldipine was approximately $5000 \mathrm{ng} / \mathrm{ml}$. Epidoxorubicin showed a concentration-dependent growth-inhibiting effect with an ID 50 of $62 \mathrm{ng} / \mathrm{ml}$. The chemosensitizer dexniguldipine at a concentration of $50 \mathrm{ng} / \mathrm{ml}$ enhanced cytotoxicity of epidoxorubicin approximately 15 times (Fig. 1). Higher concentrations of dexniguldipine were

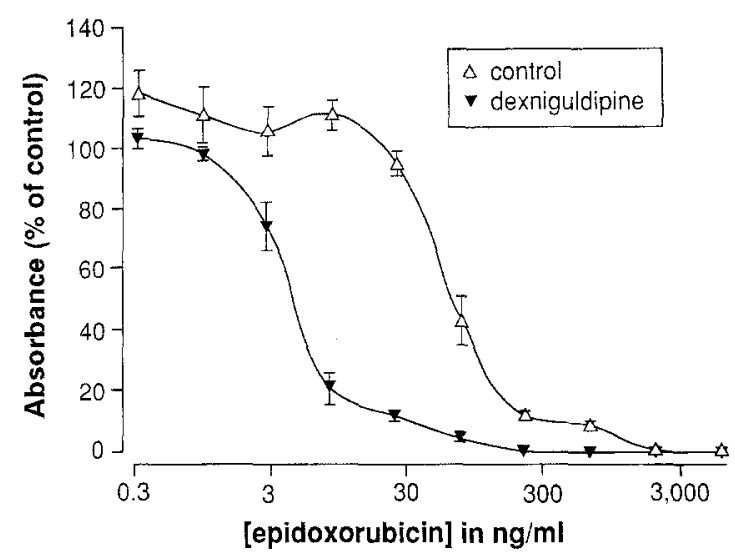

Fig. 1 Dose/response curves of the cell line CC531 to incubation with graded concentrations of epidoxorubicin in the absence $(\triangle)$ or presence $(\boldsymbol{\nabla})$ of the chemosensitizer dexniguldipine $(50 \mathrm{ng} / \mathrm{ml})$ determined in the sulphorhodamine cell viability assay. Sulphorhodamine $\mathrm{B}$ absorbance is expressed as a percentage of the control absorbance on the $y$ axis and represents the percentage cell viability.

equally effective $(500 \mathrm{ng} / \mathrm{ml})$ or too toxic for CC531 cells by themselves $(5000 \mathrm{ng} / \mathrm{ml}$ ) (data not shown).

Tissue concentrations of dexniguldipine

In this report we show some data on the levels of dexniguldipine and M-1 in plasma and in tumour tissue. In a separate report more elaborate studies on dexniguldipine and M-1 pharmacokinetics will be presented. (JHM Schellens, et al., manuscript in preparation). Dexniguldipine was readily absorbed after oral administration reaching levels in plasma after $5 \mathrm{~h}$ of 72 ( $\pm 19 \mathrm{SD}) \mathrm{ng} / \mathrm{ml}$. (see Fig. 2). Levels in tumour tissue were much higher: $925( \pm 495 \mathrm{SD}) \mathrm{ng} / \mathrm{g}$. A similar pattern was observed for the metabolite M-1: in plasma $26( \pm 6 \mathrm{SD}) \mathrm{ng} / \mathrm{ml}$ and in tumour tissue $289( \pm 127$ SD) $\mathrm{ng} / \mathrm{g}$. The level of M-1 was approximately onethird of the level of dexniguldipine.

In vivo chemosensitizing effect of dexniguldipine on epidoxorubicin

Pilot experiments with epidoxorubicin alone showed that a dose of $6 \mathrm{mg} / \mathrm{kg}$ had a moderate but consistent growth-inhibiting effect on CC531 tumours grown in the subrenal capsule assay. Dexniguldipine treatment alone had no influence on growth of the tumour. In all experiments, tumours treated with the combination dexniguldipine and epidoxorubicin were the smallest and statistical significance was reached in two experiments. The results are shown in Table 1. Dexniguldipine had no additive effect in combination with a lower dose of $4 \mathrm{mg} / \mathrm{kg}$ epidoxorubicin (data not shown). 


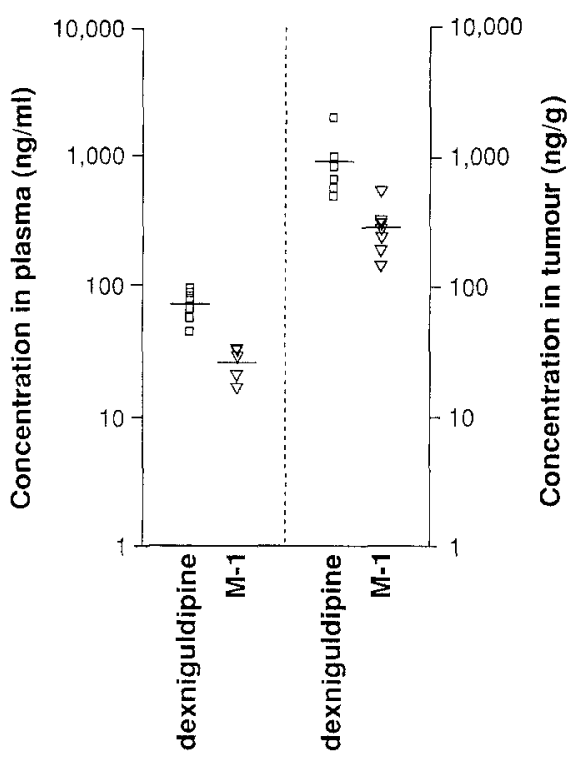

Fig. 2 Dexniguldipine $(\square)$ and $\mathrm{M}-1(\nabla)$ levels in plasma $(\mathrm{ng} / \mathrm{ml})$ and tumour tissue $(\mathrm{ng} / \mathrm{g})$ determined by HPLC $5 \mathrm{~h}$ after a single oral dose of $30 \mathrm{mg} / \mathrm{kg}$. Results from rats are represented individually on a logarithmic scale, with lines indicating the mean values. Left data from plasma; right data from tumour tissue

The experiments were not specifically designed for assessment of toxicity, but some effects on the body weight of rats were observed. Data on body weights were available from three experiments. All rats lost some weight during the experiment: control rats $1 \%-5 \%$, dexniguldipine-treated rats $2 \%-6 \%$, rats treated with epidoxorubicin alone $8 \%-12 \%$, and rats treated with the combination dexniguldipine and epidoxorubicin $9 \%-13 \%$. The total weight loss was significantly higher in the rats treated with epidoxorubicin compared to control groups. In one of the three experiments, rats treated with the combination dexniguldipine and epidoxorubicin had significantly more weight loss compared to epidoxorubicin-treated rats. In this particular experiment (number 3 ) no difference was observed in tumour weights between these groups.

\section{Discussion}

Dexniguldipine is a novel modulator of MDR that has low intrinsic calcium antagonist activity. In vitro studies have shown its efficacy as a chemosensitizer in various cytotoxicity tests and accumulation assays (Hill and Hosking 1994; Hofmann et al. 1991, 1992; Höllt et al. 1992; Reymann et al. 1993; Roller et al. 1993). Effective chemosensitizing was shown in experimental and in human tumour cell lines, and in induced as well as in intrinsic MDR. On a molar basis dexniguldipine was shown to be at least as effective as verapamil. Most studies report a superior drug-modulating effect of dexniguldipine over verapamil of 2.5- to 50-fold (Hill and Hosking 1994; Hofmann et al. 1992; Reymann et al. 1993; Roller et al. 1993).

This study expands these in vitro studies with in vivo data. After oral administration, dexniguldipine is readily absorbed and distributed into various tissues. Dexniguldipine has a very lipophilic nature and its volume of distribution is high (in animals $20-401 / \mathrm{kg}$ ) (Zech and Herzog 1991). In the present study intratumoural levels of dexniguldipine were $925 \mathrm{ng} / \mathrm{g}$ tissue, which is more than ten times the plasma levels. Compared to the in vitro level of $50 \mathrm{ng} / \mathrm{ml}$, which was effective in MDR modulation, these in vivo levels are high. The data on dexniguldipine levels were obtained after a single oral dosing. In the antitumour experiment dosing was tripled by administration on 3 consecutive days. Because of the lipophilic nature of the drug this will probably have resulted in even higher intratumoural levels. The wide variation in the results of the levels of the chemosensitizer is not readily explained. Wide interindividual variation in pharmacokinetics has been reported by others for dexniguldipine after oral administration, as well as for other dihydropyridine compounds (Ukena et al. 1995).

Part of the activity of dexniguldipine in vivo is mediated by the active metabolite $\mathrm{M}-1$, which is shown to have the same MDR-modulating potency as dexniguldipine (Hofmann et al. 1992; Höllt et al. 1992). The pharmacokinetics of $\mathrm{M}-1$ followed the results of
Table 1 Results of experiments (1-4) on tumour growth inhibition in vivo with epidoxorubicin and the chemosensitizer dexniguldipine. Standard deviations are shown in parentheses

\begin{tabular}{|c|c|c|c|c|}
\hline \multirow[t]{2}{*}{ Treatment group } & \multicolumn{4}{|c|}{ Tumour weight (mg) } \\
\hline & 1 & 2 & 3 & 4 \\
\hline Control & $45.1( \pm 15.6)$ & $34.4( \pm 7.8)$ & $20.8( \pm 6.5)$ & $41.3( \pm 9.2)$ \\
\hline Dexniguldipine & $38.6( \pm 17.9)$ & $35.1( \pm 9.0)$ & $16.4( \pm 10.6)$ & $40.6( \pm 14.9)$ \\
\hline Epidoxorubicin $6 \mathrm{mg} / \mathrm{kg}$ & $23.2( \pm 2.5)^{*}$ & $20.9( \pm 3.2)^{* *}$ & $12.3( \pm 4.2)^{*}$ & $27.2( \pm 5.1)^{*}$ \\
\hline $\begin{array}{l}\text { Epidoxorubicin } 6 \mathrm{mg} / \mathrm{kg} \\
+ \text { dexniguldipine }\end{array}$ & $18.5( \pm 10.2)^{* *}$ & $13.9( \pm 4.7)^{* * * * * *}$ & $9.9( \pm 4.1)^{*}$ & $19.6( \pm 5.2)^{* * * * * * *}$ \\
\hline
\end{tabular}

$*-* * *$ Statistically significant $(P<0.05)$ results: * epidoxorubicin or epidoxorubicin + dexniguldipine versus control; **epidoxorubicin or epidoxorubicin + dexniguldipine versus control and versus dexniguldipine; $* * *$ epidoxorubicin + dexniguldipine versus epidoxorubicin 
dexniguldipine closely. The M-1 level was approximately one-third of the level of dexniguldipine in plasma and in tumour tissue $5 \mathrm{~h}$ after administration. Recently, comparable levels of dexniguldipine and M-1 have been published from a phase I trial in patients (Ukena et al. 1995).

Dexniguldipine showed no direct antitumour activity against CC531 cells. Antiproliferative effects of dexniguldipine have been reported for some tumours, possibly tumours with a neuroendocrine differentiation depending on autocrine stimulating factors (Schüller et al. 1990, 1991). The chemosensitizing potency of dexniguldipine on the MDR CC531 tumour was observed in all in vivo experiments. Dexniguldipine had a significant potentiating effect on growth inhibition of CC531 tumours by epidoxorubicin in two out of four experiments, while in the other experiments the observed differences did not reach statistical significance. The results with dexniguldipine are comparable to those with earlier published experiments in the CC531 tumour model, which revealed the chemosensitizing effect of cyclosporin A in combination with doxorubicin (Van de Vrie et al. 1993).

Levels of epidoxorubicin in plasma and tumour have not been measured in these experiments. Therefore, we cannot rule out the possibility that altered pharmacokinetics of epidoxorubicin contribute to the chemosensitizing effect apart from direct modulation of MDR at the cellular level. The fact that combination treatment resulted in a small enhancement of toxicity in one experiment, as measured by body-weight loss, suggests that at least some systemic enhancement of epidoxorubicin activity may have occurred. This is in agreement with previous studies that showed enhancement of doxorubicin toxicity caused by combined treatment with cyclosporin A (Van de Vrie et al. 1994). Other investigators, however, have also furnished evidence for a direct effect of chemosensitizers on the tumour. Niwa et al. showed that PAK-200, like dexniguldipine a dihydropyridine analogue, enhanced the accumulation of doxorubicin in solid tumours in vivo (Niwa et al. 1992). The effect of PAK-200 on doxorubicin accumulation in the tumours was dependent on the level of P-glycoprotein expression: only the tumours with a clear expression of P-glycoprotein had a higher doxorubicin content in the presence of the chemosensitizer. Furthermore, in patients with refractory multiple myeloma, addition of cyclosporin $\mathrm{A}$ to the chemotherapeutic regimen vincristine, doxorubicin and dexamethasone resulted in enhancement of the response rate (Sonneveld et al. 1992). Additional studies showed that the effect was probably achieved by specific killing of the plasma cells expressing P-glycoprotein (Sonneveld et al. 1994). The studies clearly suggest drug modulation directly at the cellular level by a P-glycoprotein-dependent mechanism.

The results in our study are comparable to results obtained with dexniguldipine and doxorubicin in a nude mouse xenograft model. Here partial reversal of resistance to doxorubicin was observed in solid tumours of the MDR1-overexpressing KB 8.5 cell line grown subcutaneously (Boss et al. 1994). Dexniguldipine has entered clinical studies now and promising results have been obtained in trials in acute myeloid leukemia and multiple myeloma (Scheulen et al. 1995; Thaler et al. 1994).

The present study confirms the chemosensitizing potency of dexniguldipine on MDR cells in vitro. It shows that in vivo relatively high levels of dexniguldipine in plasma and tumour tissue can easily be achieved by oral administration. In vivo this resulted in a strong trend towards a significant enhancement of the antitumour effect of epidoxorubicin in the solid MDR tumour CC531.

\section{References}

Bellamy WT, Dalton WS (1994) Multidrug resistance in the laboratory and clinic. Adv Clin Chem 31:1-61

Boss H, Eisenhauer S, Ise W, Gekeler V, Sanders K-H (1994) Dexniguldipine- $\mathrm{HCl}$ modulates the MDR 1 mediated drug resistance in a nude mouse xenograft model (abstract). Anti-Cancer Drugs 5 [Suppl 1]: 29

De Greef C, Van der Heyden S, Viana F, Eggermont J, De Bruijn EA, Raeymaekers L, Droogmans G, Nilius B (1995) Lack of correlation between $m d r-1$ expression and volume activation of chloride-currents in rat colon cancer cells. Pflugers Arch 430:296-298

Echizen H, Brecht T, Niedergesäss S, Vogelgesang B, Eichelbaum M (1985) The effect of dextro-, levo-, and racemic verapamil on atrioventricular conduction in humans. Am Heart $J$ 109:210-217

Gheuens E, Van der Heyden S, Elst H, Eggermont A, Van Oosterom A, De Bruijn E (1993) Multidrug resistance in rat colon carcinoma cell lines CC531, CC531 mart and CC531 rev. Jpn J Cancer Res 84:1201-1208

Goldstein LJ, Galski H, Fojo A, Willingham M, Lai S-L, Gazdar A, Pirker R, Green A, Crist W, Brodeur GM, Lieber M, Cossman J, Gottesman MM, Pastan I (1989) Expression of a multidrug resistance gene in human cancers. J Natl Cancer Inst $81: 116-124$

Hill BT, Hosking LK (1994) Differential effectiveness of a range of novel drug-resistance modulators, relative to verapamil, in influencing vinblastine or teniposide cytotoxicity in human lymphoblastoid CCRF-CEM sublines expressing classic or atypical multidrug resistance. Cancer Chemother Pharmacol 33:317-324

Hofmann J, Ueberall F, Egle A, Grunicke H (1991) B-859-35, a new drug with anti-tumour activity reverses multi-drug resistance. Int J Cancer 47:870-874

Hofmann J, Wolf A, Spitaler M, Böck G, Drach J, Ludescher C, Grunicke H (1992) Reversal of multidrug resistance by B859-35, a metabolite of B859-35, niguldipine, verapamil and nitrendipine. $\mathrm{J}$ Cancer Res Clin Oncol 118:361-366

Höllt V, Kouba M, Dietel M, Vogt G (1992) Stereoisomers of calcium antagonists which differ markedly in their potencies as calcium blockers are equally effective in modulating drug transport by P-glycoprotein. Biochem Pharmacol 43:2601-2608

Marquet RL, Westbroek DL, Jeekel J (1984) Interferon treatment of a transplantable rat colon adenocarcinoma: importance of tumour site. Int $J$ Cancer 33:689-692 
Niwa K, Yamada K, Furukawa T, Shudo N, Seto K, Matsumoto T, Takao S, Akiyama S-i, Shimazu H (1992) Effect of a dihydropyridine analogue, 2-[benzyl(phenyl)amino]ethyl 1,4dihydro-2,6-dimethyl-5-(5,5-dimethyl-2-oxo-1,3,2-dioxaphosphorian-2-yl)-1-(2-morpholinoethyl)-4-(3-nitrophenyl)-3-pyridinecarboxylate on reversing in vivo resistance of tumour cells to Adriamycin. Cancer Res 52:3655-3660

Pennock GD, Dalton WS, Roeske WR, Appleton CP, Mosley K, Plezia P, Miller TP, Salmon SE (1991) Systemic toxic effects associated with high-dose verapamil infusion and chemotherapy administration. J Natl Cancer Inst 83:105-110

Plumb JA, Milroy R, Kaye SB (1990) The activity of verapamil as a resistance modifier in vitro in drug resistant human tumour cell lines is not stereospecific. Biochem Pharmacol 39:787-792

Reymann A, Looft G, Woermann C, Dietel M, Erttmann R (1993) Reversal of multidrug resistance in Friend leukemia cells by dexniguldipine- $\mathrm{HCl}$. Cancer Chemother Pharmacol 32:25-30

Roller E, Klumpp B, Krause J, Eichelbaum M. Schumacher K (1993) Influence of sequential exposure to R-verapamil or B8509-035 on rhodamine 123 accumulation in human lymphoblastoid cell lines. Cancer Chemother Pharmacol 32:151-155

Scheulen ME, Meusers P, Schröder J, Uppenkamp M, Müller M, Reiter WW, Weimar Ch, Rathgeb F, Brittinger G, Seeber $\mathrm{S}$ (1995) Phase I/II trial of additive dexniguldipine (hADM) in acute myeloid leukemia (AML) refractory to previous daunorubicin and high-dose cytarabine (hAD) (abstract). Proc Am Assoc Cancer Res 36:203

Schüller HM, Correa E, Orloff M, Reznik GK (1990) Succesful chemotherapy of experimental neuroendocrine lung tumours in hamsters with an antagonist of $\mathrm{Ca}^{2+} /$ calmodulin. Cancer Res 50:1645-1649

Schüller HM, Orloff M, Reznik GK (1991) Antiproliferative effects of the $\mathrm{Ca}^{2+}$ /calmodulin antagonist $\mathrm{B} 859-35$ and the $\mathrm{Ca}^{2+}$-channel blocker verapamil on human lung cancer cell lines. Carcinogenesis 12:2301-2303
Skehan P, Storeng R, Scudiero D, Monks A, McMahon J, Vistica D, Warren JT, Bokesch H, Kenney S, Boyd MR (1990) New colorimetric cytotoxicity assay for anticancer-drug screening. J Natl Cancer Inst 82:1107-1112

Sonneveld P, Durie BGM, Lokhorst HM, Marie JP, Solbu G, Suciu S, Zittoun R, Löwenberg B, Nooter K (1992) Modulation of multidrug-resistant multiple myeloma by cyclosporin. Lancet 340:255-259

Sonneveld P, Schoester M, De Leeuw K (1994) Clinical modulation of multi-drug resistance in multiple myeloma: effect of cyclosporine on resistant tumour cells. J Clin Oncol 12:1584-1591

Thaler J, Reiter WW, Ludescher C, Wörmann B, Ramsauer B, Nüßler V, Reiber C, Weimar C, Nowrousian MR (1994) Modulation of multidrug resistance (MDR1) by dexniguldipine in combination with VAD or VECD in patients with refractory myeloma (abstract). Onkologie 17 [Suppl 2]:abstract 603

Ukena D, Boewer C, Oldenkott B, Rathgeb F, Wurst W, Zech K, Sybrecht GW (1995) Tolerance, safety, and kinetics of the new antineoplastic compound dexniguldipine- $\mathrm{HCl}$ after oral administration: a phase I dosemescalation trial. Cancer Chemother Pharmacol 36:160-164

Van de Vrie W, Gheuens EEO, Durante NMC, De Bruijn EA, Marquet RL, Van Oosterom AT, Eggermont AMM (1993) In vitro and in vivo chemosensitizing effect of cyclosporin $\mathrm{A}$ on an intrinsic multidrug-resistant rat colon tumour. J Cancer Res Clin Oncol 119:609-614

Van de Vrie W, Jonker AM, Marquet RL, Eggermont AMM (1994) The chemosensitizer cyclosporin A enhances the toxic sideeffects of doxorubicin in the rat. $\mathbf{J}$ Cancer Res Clin Oncol 120:533-538

Zech K, Herzog R (1991) Two-dimensional high-performance liquid chromatography at low $\mathrm{ng} / \mathrm{ml}$ levels of the anti-proliferative agent B859-35 in serum with automated sample clean-up, solidphase trapping and ultraviolet detection. J Chromatogr 553:55-63 